\title{
PREDIKSI PERKEMBANGAN LAHAN PERMUKIMAN TERHADAP KERENTANAN BENCANA BANJIR DAN KEBAKARAN DI PERMUKIMAN TEPIAN SUNGAI KAPUAS KOTA PONTIANAK
}

\author{
Prediction of Settlement's Areas Development to Flood and Fire \\ Disaster Vulnerability in The Kapuas Riverbanks Settlements of \\ Pontianak City
}

\section{Ely Nurhidayati' ${ }^{1}$, Imam Buchori², M. Mussadun²}

Diterima: 19 Oktober 2016 Disetujui: 28 November 2016

\begin{abstract}
Abstrak: Permukiman rumah panggung di Kecamatan Pontianak Timur terletak pada muara percabangan Sungai Kapuas dan Sungai Landak. Penelitian ini dilakukan untuk mengetahui perubahan guna lahan permukiman tahun 2003-2014, memprediksi lahan permukiman tahun 2020 dan mengetahui korelasi kerentanan bencana terhadap prediksi perkembangan lahan permukiman di tepian Sungai Kapuas. Metode penelitian ini menggunakan teknik kuantitatifSIG yang mengintegrasikan analisis regresi logistik biner dan CA-Markov. Data yang digunakan adalah citra satelit Quickbird 2003, IKONOS 2008 dan data elevasi kontur interval 1 meter. Hasil penelitian menunjukkan akurasi prediksi sebesar $79,74 \%$ dan indeks kappa tertinggi sebesar 0,55. Hasil prediksi luas lahan permukiman sebesar 481,98 Ha pada tahun 2020 yang menunjukkan ekspansi lahan tertinggi di Kelurahan Parit Mayor dan peningkatan lahan permukiman sebesar 6,80 Ha/tahun (2014-2020). Hasil analisis regresi memiliki koefisien 0 pada variabel banjir, artinya bencana banjir tidak berpengaruh terhadap perkembangan lahan permukiman di Kecamatan Pontianak Timur.
\end{abstract}

Kata kunci: prediksi; lahan permukiman; kerentanan bencana; rumah panggung.

\begin{abstract}
Settlements of house on stilts in the Eastern Pontianak is located at the triangle of the Kapuas River and Landak River. This study to determine the changes of settlement's areas in 2003-2014, predict the settlement's areas in 2020 and the correlation between the disaster vulnerability and the development of settlement's areas in the Kapuas riverbanks. This research method integrates quantitative-SIG binary logistic regression and CA-Markov. The data used are Quickbird satellite imagery (2003), elevation data ICONOS (2008) and contour intervals (1 meter). The results are the prediction accuracy $(79.74 \%)$ and the highest kappa index (0.55). The prediction of settlement's areas (481.98 hectares) in 2020, shows the highest land expansion in the Parit Mayor Village and the increase of settlement's areas (6.80 ha/year) in 2014-2020. Regression analysis have a coefficient of 0 in the flooding variable, so the floods did not affected the development of settlement's areas in the Eastern Pontianak.
\end{abstract}

Keywords: prediction; settlement's areas; disaster vulnerability; house on stilts.

\footnotetext{
${ }^{1}$ Jurusan Teknik Arsitektur, Politeknik Negeri Pontianak

${ }^{2}$ Departemen Perencanaan Wilayah dan Kota, Fakultas Teknik, Universitas Dipoengoro
} 


\section{PENDAHULUAN}

Perubahan iklim dan dampaknya terhadap lingkungan, ekonomi, sosial, budaya dan keamanan merupakan isu yang semakin berkembang sejak lama. Di perkotaan, perubahan iklim berkaitan dengan proses dan transformasi pada ekonomi global, migrasi, urbanisasi, keragaman populasi, keterpaparan dan kerentanan. Wilayah pesisir adalah daerah yang paling rentan terhadap perubahan iklim. Peningkatan muka air laut akan menimbulkan banjir genangan, cuaca ekstrim dan pengikisan lahan pesisir.

Fenomena perubahan iklim global diantaranya akibat dari kenaikan permukaan laut yang menimbulkan risiko serius bagi zona pesisir, habitat dan sumber daya merupakan masalah yang banyak dihadapi masyarakat pesisir di negara berkembang (Sales 2009; Jabareen 2013; Nema et al. 2012). Perubahan iklim adalah pergeseran yang mengubah komposisi atmosfer global, yang disebabkan secara langsung atau tidak langsung dari kegiatan manusia (IPCC 2002; Laukkonen et al. 2009 ; UNFCC dalam Satarm 2012; UU Nomor 30 Tahun 1999).

Perkembangan kota khususnya di negara kepaulauan memiliki bentuk keruangan yang beragam diantara keruangan kota berbasis air seperti laut, danau, pantai, pesisir, sungai dan rawa. Format keruangan tersebut umumnya berada di kota besar di Indonesia yang berada di tepian laut dan sungai, dimana secara historis kawasan embrional di tepian air berperan penting dalam perkembangan kota menjadi kota besar. Salah satunya elemen embrio tradisional pembentukan ruang kota perairan di Pontianak, dimana formasi kotanya berbasis sungai yang perluasan kota umumnya menuju daratan dimana secara historis pola keruangan kawasan kerajaan dan nelayan dengan kawasan kolonial Belanda merupakan kawasan baru yang terpisah (Mentayani et al. 2013).

Menurut laporan IPCC ke-4 menyebutkan bahwa perubahan muka air laut rata-rata selama abad 20 adalah $0,17(0,12-1,22)$ meter dan diproyeksikan akan meningkat hingga $0,59(0,18-0,59)$ meter pada tahun 2100. Ketinggian muka air laut rata-rata 0,59 meter tersebut merupakan batas pasang tertinggi saat ini (IPCC 2007). Fakta tersebut menunjukkan bahwa kenaikan muka air laut rata-rata telah diprediksikan tersebut akan menjadi ancaman bagi hampir semua lahan pesisir terutama yang berelevasi rendah.

Kota yang kompleks terutama di negara berkembang, sering menunjukkan tingkat kerentanan yang tinggi terhadap bencana, karena mereka memiliki konsentrasi pusat kegiatan, ketergantungan infrastruktur, perekonomian, kemiskinan dan persaingan politik (United Nations Human Settlements Program/UNHSP, 2004). Banyak bencana terjadi di permukiman padat penduduk karena kegiatan manusia, ekonomi, sosial dan kerusakan lingkungan berdampak negatif pada pembangunan nasional dan daerah (Bash 2009). Indonesia adalah negara kepulauan tropis yang terdiri dari atas gugusan pulau-pulau yang saling dihubungkan dengan lautan. Berdasarkan hasil survey Kementrian Kelautan dan Perikanan (KKP) tahun 2010, jumlah pulau terdiri atas 13.000 pulau. Indonesia juga memiliki garis pantai terpanjang keempat di dunia yaitu $95.181 \mathrm{~km}$. Konsekuensi dari luasnya wilayah kepesisiran adalah tidak terlepas dari ancaman bahaya.

Keragaman geomorfologi dan intensitas permukiman merupakan dasar dalam menentukan perubahan di daerah pemukiman, sehingga setiap kawasan tepian air dan kota pesisir memiliki karakteristik yang berbeda, tergantung pada proses geologi yang terjadi. Faktor penting dalam permukiman adalah jarak dari sumber air. Dalam pola pemukiman, pemodelan diperlukan untuk menilai dampak banjir di permukiman tepian sungai, hal tersebut disebabkan karena perilaku manusia dalam mengelola sumber daya air karena dan kapasitas manajemen sumber air (Anunobi A.I, 2014; Jaroslaw \& Hildebrandt-Radke, 2009; Nwilo et al., 2012; Watson \& Adams, 2011). 


\section{METODOLOGI}

Penelitian ini mengintegrasikan metode kuantitatif dengan Sistem Informasi Geografis (SIG) berbasis CA-Markov dan regresi logistik biner, dimana SIG diperlukan untuk mengkonversi variabel-variabel aturan transisi dalam bentuk spasial, luas lahan dan perhitungan matematis.

Model selular automata umumnya digunakan untuk memprediksi pengembangan lahan yang merupakan proses sejarah tergantung dimana pembangunan itu dilakukan, baik dimasa lalu yang mungkin mempengaruhi masa depan melalui interaksi lokal antara bidang tanah (Wu dan Webster, 1998). Dalam CA simulasi, hasilnya dari iterasi sebelumnya memainkan peran penting pada hasil iterasi berturut-turut. pola global yang kompleks dapat dibentuk setelah banyak iterasi simulasi. Wu (1998) menjelaskan bahwa beberapa fitur yang tak terduga mungkin dapat muncul selama simulasi dengan benar mendefinisikan aturan transisi.

Dalam konsep kerangka kerja GIS, analisis spasial lebih terfokus pada menyelidiki pola, atribut, dan gambaran daerah menggunakan pemodelan untuk meningkatkan pemahaman dan prediksi (Rustiadi, 2009). pusat distribusi spasial telah banyak dibahas dalam teori lokasi spasial seperti Von Thunen mana berbagai pusat memiliki efek yang berbeda pada pola penggunaan lahan. Dalam rangka untuk menemukan variabel yang relevan digunakan dalam penelitian ini, kita dapat mengacu pada pendekatan spasial dan ekologis (Yunus, 2010) atau apa yang disebut sebagai pendekatan regional kompleks dikombinasikan dengan model CA.

Dalam menentukan transition rules sama halnya dengan menentukan faktor penarik dan pendorong perkembangan permukiman yang dapat ditentukan oleh sebab-sebab suatu daerah dapat berkembang. Hoyt (dalam Syahar, 2012) menyatakan tentang teori kecenderungan sektorisasi, bahwa daerah-daerah yang berpotensi untuk berkembang cepat (High Quality Areas) ada 10 lokasi. Akan tetapi yang terkait dengan tema penelitian ini diantaranya, permukiman cenderung berkembang pada jalur transportasi/ke arah pusat perdagangan, permukiman cenderung berkembang pada jalur transportasi yang ada dan permukiman cenderung berkembang pada arah yang sama dalam kurun waktu periode yang lama.

Sehubungan dengan paparan diatas, maka dalam penelitian ini menggunakan beberapa variabel sebagai faktor pendorong perkembangan permukiman antara lain; (1) Jarak terhadap jalan utama; (2) Jarak terhadap jalan kolektor; (3) Kawasan potensi banjir; (4) Jarak terhadap Keraton Kadariah, kawasan pariwisata dan pusat pemerintahan; (5) Jarak terhadap pusat ekonomi dan pelayanan jasa; (6) Jarak terhadap fasilitas berupa rumah sakit dan perguruan tinggi; (7) Jarak terhadap utilitas berupa dermaga dan terminal bus; dan (8) Jarak terhadap permukiman eksisting.

\section{Lokasi dan Data Penelitian}

Lokasi studi dalam penelitian ini terletak di Kecamatan Pontianak Timur, Kota Pontianak, Provinsi Kalimantan Barat. Obyek penelitian ini adalah permukiman yang berada pada kawasan waterfront city dan kawasan cultural heritage Pontianak, selain itu salah satu kawasan permukiman dinamakan Kampung Beting di Kecamatan Pontianak Timur, merupakan kampung cikal bakal lahirnya Kota Pontianak (Hasanuddin, 2015). Peraturan kebijaksanaan Pemerintah Kota Pontianak dalam Penataan Ruang Kota Pontianak yang berorientasi Waterfront City (Kajian Kritis Undang-Undang Nomor 24/1992), menjelaskan Pontianak merupakan salah satu wilaya provinsi yang merupakan daerah otonom yang mempunyai tipikal kota air. Kawasan permukiman dalam penelitian ini merujuk dari Undang-Undang Nomor 4/1992 Tentang Perumahan dan Permukiman, 
permukiman adalah bagian dari lingkungan hidup di luar kawasan lindung, baik yang berupa kawasan perkotaan maupun perdesaan yang berfungsi sebagai lingkungan tempat tinggal atau lingkungan hunian dan tempat kegiatan yang mendukung perikehidupan dan penghidupan. Adapun data yang digunakan dalam penelitian ini antara lain:

- Citra satelit Quickbird tahun 2003 dari Google Earth

- Citra satelit IKONOS tahun 2008 dari BAPPEDA Kota Pontianak

- Data kontur interval 1 meter dari BAPPEDA Kota Pontianak

\section{Teknik Penelitian}

Penelitian ini menggunakan citra satelit unduhan dari Google Earth mengingat sulitnya meperoleh citra resolusi tinggi untuk wilayah kajian. Dalam penelitian Yuanita dkk (2013) menunjukkan citra Quickbird yang didapat dari Google Earth memiliki nilai RMSe yang rendah pada daerah yang relatif datar dibandingkan daerah yang relatif tinggi sedangkan wilayah kajian dalam penelitian ini adalah wilayah yang relatif datar pula.

Citra satelit ini kemudian diinterpretasikan sehingga diperoleh informasi penutup lahannya. Klasifikasi yang digunakan adalah klasifikasi dari Danoedoro (2012) \& USGS (2015) yang dimodifikasi. Dasar modifikasi klasifikasi tersebut adalah melihat tujuan serta karakteristik daerah penelitian, modifikasi dilakukan dengan membagi penutup menjadi 3 kelas, yaitu permukiman, non-permukiman dapat dikoversi, dan non-permukiman tidak dapat dikonversi. Non-permukiman dapat dikoversi meliputi tutupan lahan berupa lahan kosong dan area vegetasi, sedangkan non-permukiman tidak dapat dikonversi meliputi tutupan lahan berupa tubuh air ditambah bagian dari tutupan lahan terbangun yaitu industri dan gedung.

Variabel terkait jarak dalam penelitian ini dibangun dengan menggunakan analisis Euclidean Distance, sedangkan variabel kawasan berpotensi banjir dibangun dari DEM (Digital Elevation Model) yang dibuat dari data kontur interval 1 meter. Berdasarkan data pasang surut Sungai Kapuas dari Badan Meteorologi dan Klimatologi Kota Pontianak (2013) pasang tertinggi adalah 1,9 meter. Oleh karena itu dapat diasumsikan bahwa medan dengan ketinggian dibawah 1,9 meter adalah kawasan berpotensi banjir.

Selain itu, dalam penelitian ini juga menambahkan variabel kepadatan bangunan. Bangunan yang dimaksud meliputi permukiman, gedung dan industri. Variabel ini mewakili salah satu faktor penghambat perkembangan permukiman di Kecamatan Pontianak Timur yaitu kerentanan kebakaran. Wilayah dengan bangunan yang padat memiliki kerentanan yang tinggi terhadap kebakaran, selain itu variabel kepadatan (Hoyt dalam Syahar, 2012) yaitu permukiman cenderung berkembang pada daerah yang terbuka untuk pengembangan selanjutnya open country dan tidak terdapat penghalang fisikal yang berarti. Variabel kepadatan bangunan diperoleh dengan menggunankan analisis Kernell Density.

Dalam pembuatan model prediksi perkembangan permukiman dalam penelitian ini menggunakan intergrasi regresi logistik biner dengan CA Markov. Model ini digunakan oleh Wijaya dan Susilo (2013) dalam memprediksi perkembangan lahan terbangun di Kota Salatiga dengan mendapatkan overall akurasi $78,20 \%$ serta indeks kappa 0,48. Penilitian ini berbeda dengan penelitian Wijaya dan Susilo (2013), dalam penelitian ini tidak mempertimbangkan jumlah sel yang diprediksi akan berubah.

Model CA-Markov ini menggunakan data berbasis raster, oleh karena itu semua data yang digunakan dalam penelitian ini dikonversi dalam bentuk raster dengan ukuran 10 meter x 10 meter. Data tahun 2003 dan 2008 akan dijadikan dasar prediksi perkembangan lahan permukiman pada tahun 2014, hasil prediksi akan diuji akurasinya (ketelitiannya) kemudian dilakukan prediksi kembali pada tahun 2020. 

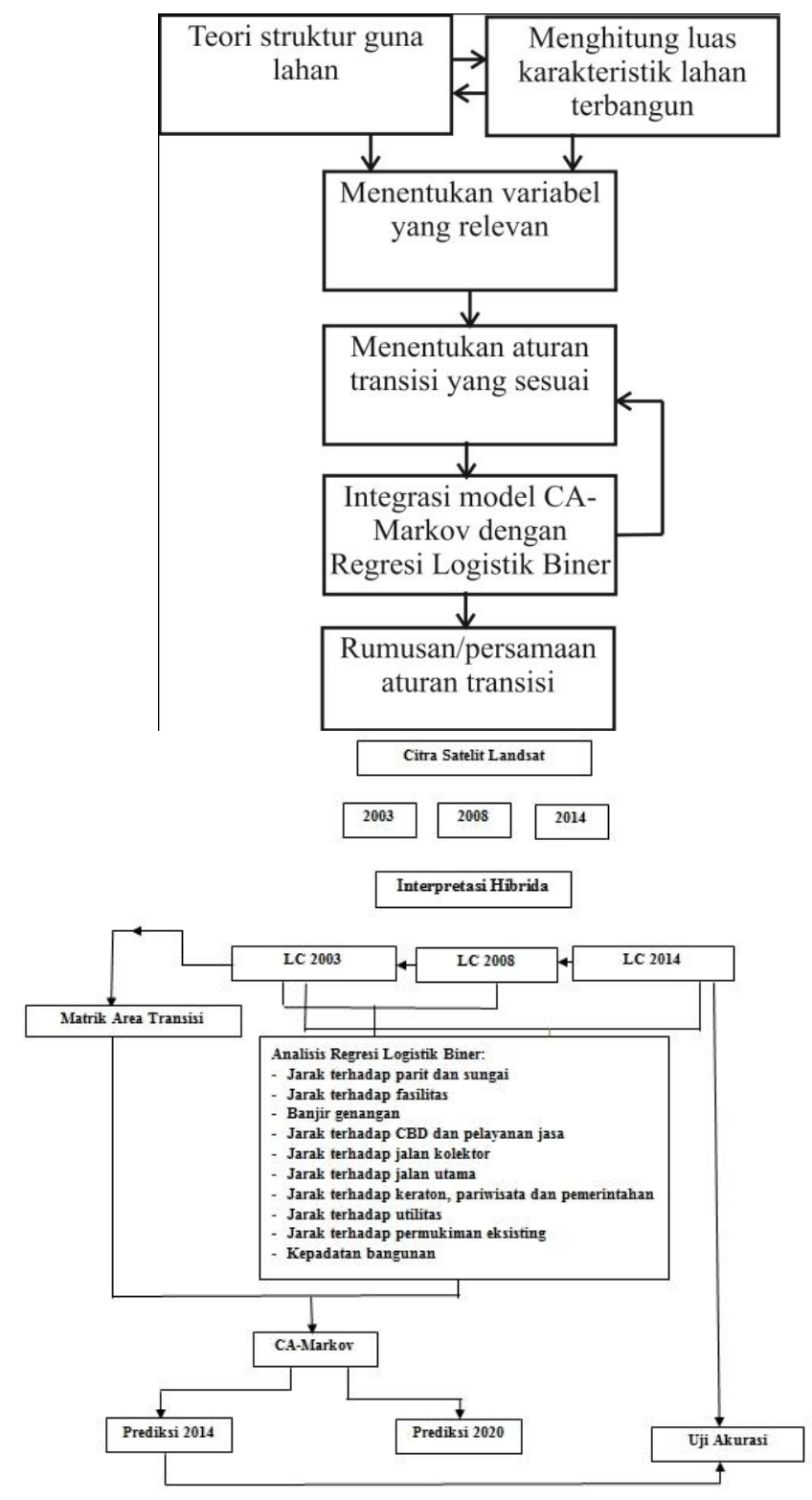

Gambar 1. (A) Prosedur Dalam Menentukan Aturan Transisi (B) Kerangka Pemodelan CA.

\section{HASIL DAN PEMBAHASAN}

Hasil penelitian ini terbagi kedalam tiga sub judul analisis, antara lain perubahan lahan permukiman, prediksi perkembangan lahan permukiman, serta korelasi banjir dan kepadatan bangunan terhadap prediksi perkembangan lahan permukiman. Untuk lebih jelasnya akan diuraikan berikut ini.

\section{Perubahan Lahan Permukiman}

Berdasarkan hasil analisis perubahan perubahan penutup lahan tahun 2003 sampai 2008, diketahui bahwa dalam kurun waktu tersebut terjadi peningkatan luasan permukiman di Kecamatan Pontianak Timur sebesar 38,49 Ha. Luas lahan permukiman di Kecamatan 
Pontianak Timur pada tahun 2008 yaitu 397,35 Ha yang sebelumnya adalah seluas 358,86 Ha pada tahun 2003.

Hasil analisis menggunakan interpolasi spasial polynomial orde 3 terhadap lokasi ekspansi lahan permukiman pada tahun tahun 2003 sampai 2008 di Kecamatan Pontianak Timur, menunjukkan pusat perkembangan lahan terbangun berada di daerah tengah dan timur, lebih tepatnya di Kelurahan Dalam Bugis bagian timur, Kelurahan Tanjung Hulu bagian selatan dan Kelurahan Saigon bagian utara. Berdasarkan hasil pengamatan, wilayah tersebut sebelum berubah menjadi lahan permukiman adalah berupa semak belukar dan kebun campuran (gambar 4).

Analisis faktor pendorong perubahan lahan permukiman menggunakan regresi logistik biner antara perubahan tutupan lahan non-permukiman menjadi lahan permukiman tahun 2003-2008 menghasilkan persamaan regresi sebagai berikut:

$\mathrm{Y}=-3.6640+0.000877 * \mathrm{X} 1-0.000000 * \mathrm{X} 2+0.000358 * \mathrm{X} 3+0.000843 * \mathrm{X} 4-0.001819 * \mathrm{X} 5+$ $0.000382 * X 6-0.000505 * X 7+0.000684 * X 8+0.004674 * X 9-0.264610 * X 10$.

Dimana:

$\mathrm{Y} \quad$ : Logit perubahan guna lahan dari non-permukiman ke permukiman

$\mathrm{X} 1 \quad$ : Jarak terhadap sungai dan parit

$\mathrm{X} 2$ : Jarak terhadap fasilitas

X3 : Banjir

X4 : Jarak terhadap pusat bisnis (CBD) dan pelayanan jasa

X5 : Jarak terhadap jalan kolektor

X6 : Jarak terhadap jalan utama

X7 : Jarak terhadap Keraton Kadariah, pariwisata dan pemerintahan

X8 : Jarak terhadap utilitas

X9 : Jarak terhadap permukiman eksisting

X10 : Kepadatan bangunan

Persamaan (1) diatas menunjukkan koefisien regresi paling besar terdapat pada variabel jarak terhadap permukiman eksisting yaitu sebesar 0,26 . Nilai positif menunjukkan bahwa semakin besar nilai variabel independen, semakin besar kemungkinan terjadi perubahan penutup lahan non-permukiman menjadi permukiman pada lokasi tersebut, sedangkan nilai negatif adalah sebaliknya dimana menunjukkan bahwa semakin kecil nilai variabel independen semakin besar kemungkinan terjadi perubahan penutup lahan nonpermukiman menjadi permukiman.

Variabel jarak terhadap permukiman existing memiliki yang pengaruh yang paling signifikan terhadap perubahan lahan non-permukiman menjadi permukiman memiliki nilai negatif, jadi dapat diketahui bahwa semakin dekat jarak dengan permukiman eksisting maka semakin besar juga kemungkinan lahan tersebut berubah dari non-permukiman menjadi permukiman.

Koefisien regresi paling kecil adalah variabel banjir atau genangan yaitu 0 . Berdasarkan hal tersebut, variabel banjir atau genangan tidak memiliki pengaruh sama sekali terhadap perubahan lahan non-permukiman menjadi permukiman.

Banjir atau genangan yang terjadi di Kecamatan Pontianak Timur tidak mempengaruhi perkembangan permukiman di kawasan ini, karena tingkat adaptasi masyarakat terhadap struktur bangunan pada permukiman rumah panggung sangai baik, melalui rekayasa pada pondasi rumah panggung yang telah menyesuaikan dengan ketinggian genangan pada saat banjir pasang (gambar 2). 


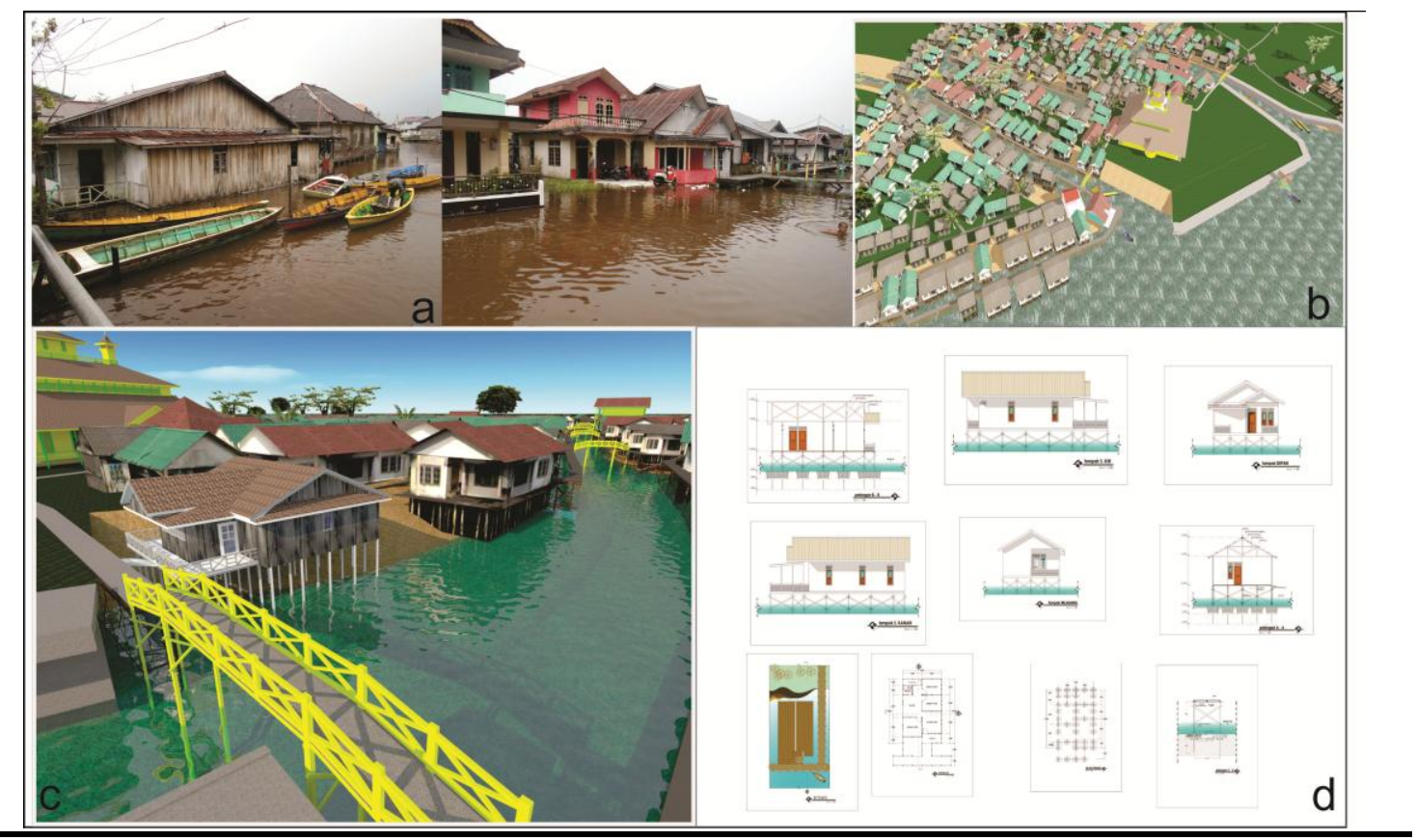

Gambar 2. (a) Banjir Pasang di Permukiman Rumah Panggung; (b/c) Perspektif Permukiman Rumah Panggung; (d) Denah Rumah Panggung.

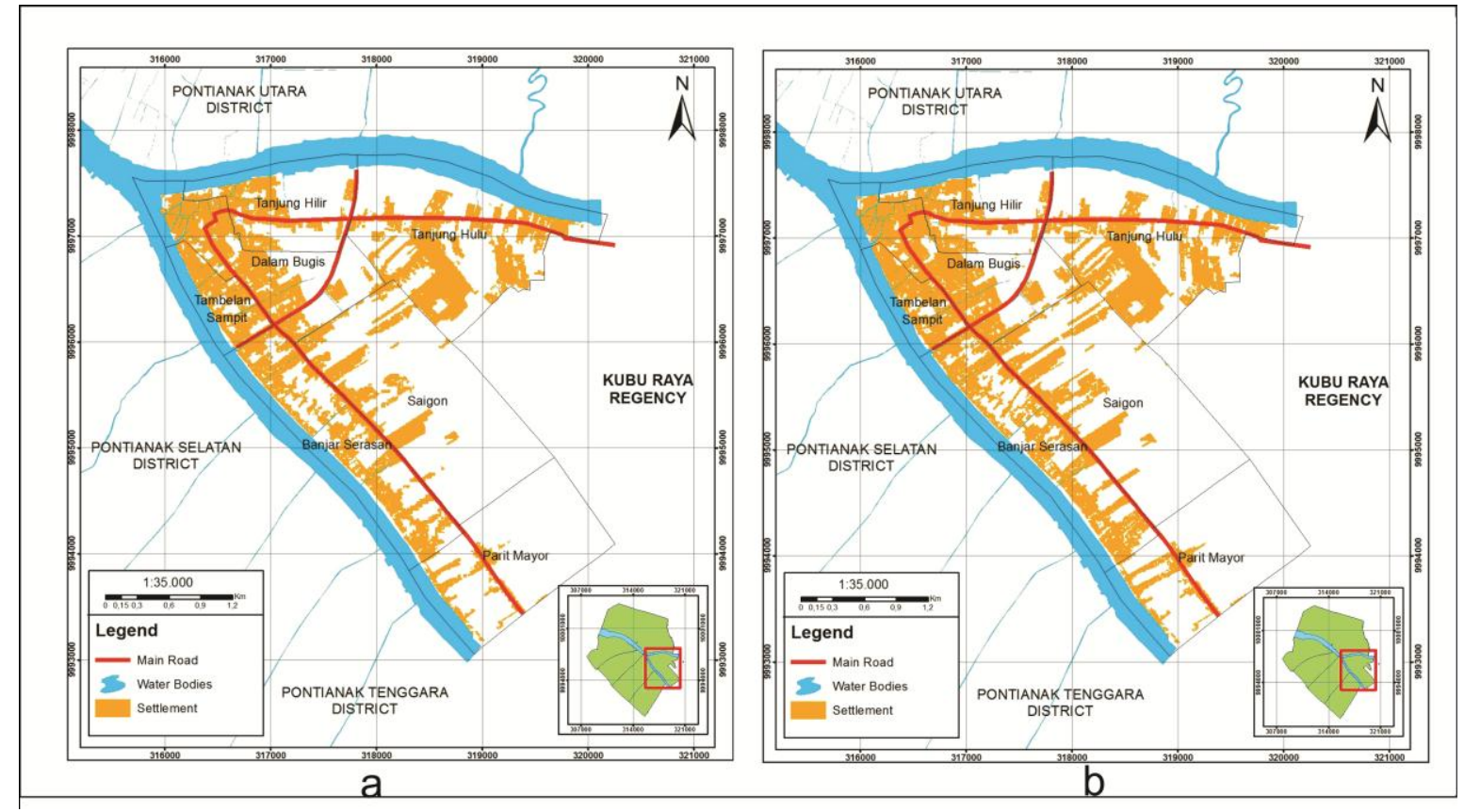

Gambar 3. (a) Peta Lahan Permukiman Eksisting (2003); (b) Peta Lahan Permukiman Eksisting (2008).

\section{Prediksi Perkembangan Lahan Permukiman}

Luasan hasil prediksi lahan permukiman pada tahun 2014 adalah 440,82 Ha, hasil prediksi lebih kecil 0,35 Ha dari luasan permukiman kota pontianak adalah sebesar 441,17 Ha. Hasil uji akurasi menunjukan bahwa prediksi perubahan permukiman di Kecamatan 
Pontianak Timur mampu mendapatkan overall akurasi sebesar 79,74\% serta indeks kappa tertinggi 0,55. Berdasarkan hal tersebut dapat dikatakan bahwa model prediksi lahan permukiman menggunanan Cellular Automata (CA)-Markov dapat diterima dan akan digunakan untuk memprediksi keadaan permukiman pada tahun 2020 (gambar 3). Hasil prediksi menunjukkan bahwa pada tahun 2020 lahan permukiman seluas 481,98 Ha. Selama kurun waktu 6 tahun pada tahun 2014-2020 terjadi peningkatan luasan permukiman sebesar 40,81 Ha atau sebesar 6,80 Ha/tahun.

Berdasarkan hasil analisis menggunakan interpolasi spasial polynomial orde 3 terhadap lokasi ekspansi lahan permukiman pada tahun 2020 di Kecamatan Pontianak Timur menunjukkan wilayah perkembangan lahan permukiman cukup merata di Kelurahan Saigon, Kelurahan Tanjung Hulu, Kelurahan Banjar Serasan dan perkembangan paling tinggi di Kelurahan Parit Mayor (gambar 4).

$$
\begin{aligned}
\mathrm{Y}= & 4.4328-0.001154^{\star} \mathrm{X} 1+0.002352 * \mathrm{X} 2+0.000000^{\star} \mathrm{X} 3-0.001400^{\star} \mathrm{X} 4+0.005696^{\star} \mathrm{X} 5 \\
& -0.001250^{\star} \mathrm{X} 6+0.002758^{\star} \mathrm{X} 7-0.002166^{\star} \mathrm{X} 8-0.754588^{\star} \mathrm{X} 9+0.003258^{\star} \mathrm{X} 10 \ldots \ldots \ldots \ldots
\end{aligned}
$$

Dimana:

Y : Logit perubahan guna lahan dari non-permukiman ke permukiman

$\mathrm{X} 1 \quad$ : Jarak terhadap sungai dan parit

$\mathrm{X} 2$ : Jarak terhadap fasilitas

X3 : Banjir

X4 : Jarak terhadap pusat bisnis (CBD) dan pelayanan jasa

X5 : Jarak terhadap jalan kolektor

X6 : Jarak terhadap jalan utama

X7 : Jarak terhadap Keraton Kadariah, pariwisata dan pemerintahan

X8 : Jarak terhadap utilitas

X9 : Jarak terhadap permukiman eksisting

X10 : Kepadatan bangunan

Persamaan (2) diatas menunjukkan koefisien regresi paling besar terdapat pada variabel jarak terhadap permukiman eksisting yaitu sebesar $-0,75$. Variabel jarak terhadap permukiman existing memiliki yang pengaruh yang paling signifikan terhadap perubahan lahan non-permukiman menjadi permukiman karena memiliki nilai negatif. Jadi dapat diketahui bahwa semakin dekat jarak dengan permukiman eksisting, maka semakin besar juga kemungkinan lahan tersebut berubah dari non-permukiman menjadi permukiman. Selain itu, jarak terhadap jalan utama dan tingkat kepadatan bangunan juga berpengaruh cukup tinggi terhadap perubahan lahan dari non-permukiman ke permukiman. Sama seperti logit perubahan lahan permukiman tahun 2003 ke tahun 2008, koefisien regresi paling kecil adalah variabel banjir (0). Berdasarkan hal tersebut, variabel banjir atau genangan tidak memiliki pengaruh sama sekali terhadap perubahan lahan non-permukiman menjadi permukiman.

Berdasarkan persamaan diatas, maka ditemukan bahwa Kelurahan Parit Mayor menjadi pusat perkembangan permukiman di Pontianak Timur pada tahun 2020. Hal ini disebabkan karena Kelurahan Parit Mayor masih memiliki kantong lahan non-terbangun, sehingga masih dapat dikembangkan menjadi kawasan terbangun seperti permukiman. Selain itu ditinjau dari faktor aksebilitas di Kelurahan Parit Mayor dilewati jalan utama untuk menuju jembatan penyeberangan Tol Kapuas II dan Trans Kalimantan (gambar 5). 


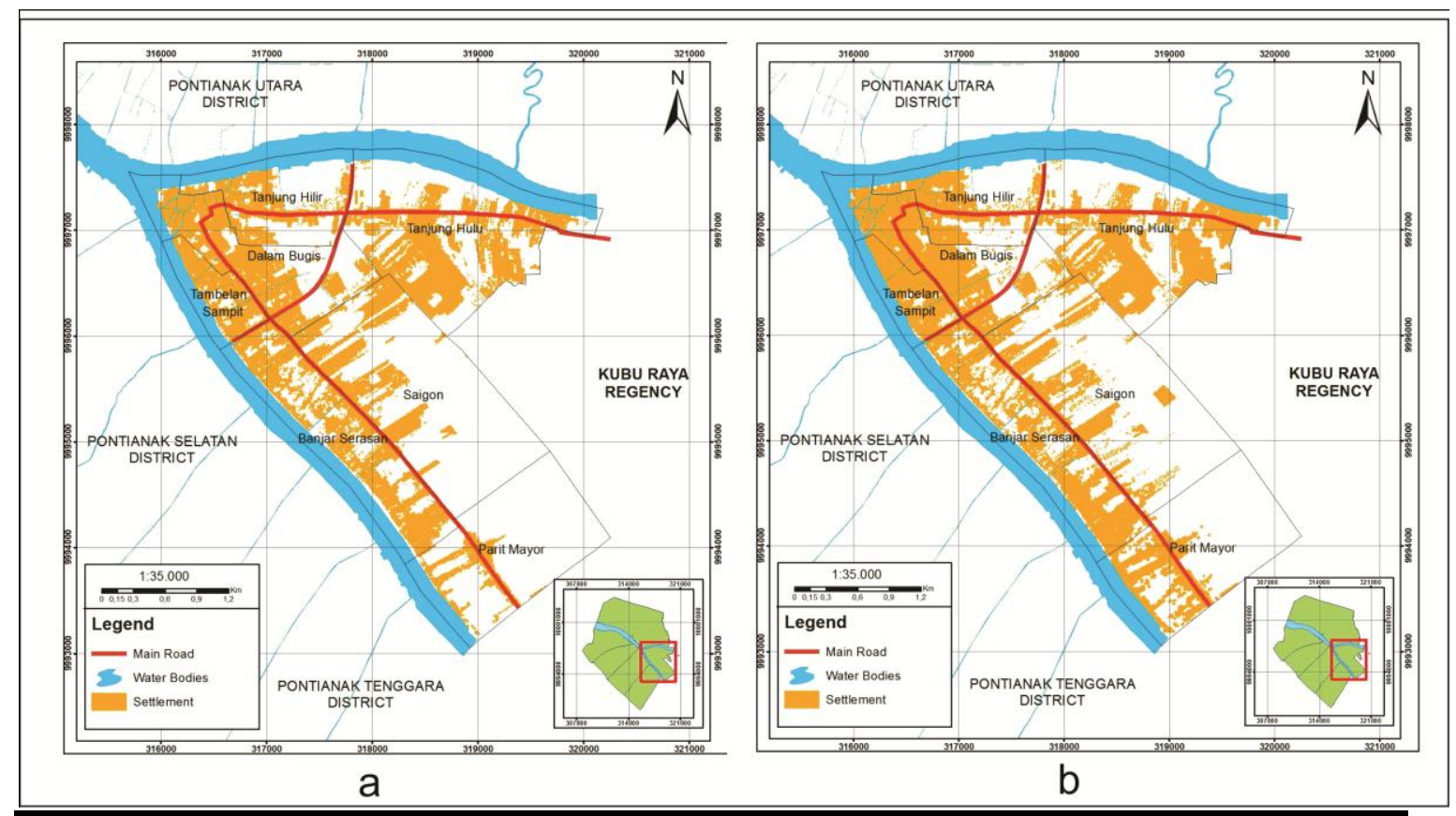

Gambar 4. (a) Peta Perkembangan Lahan Permukiman (2014); (b) Peta Perkembangan Lahan Permukiman (2020).

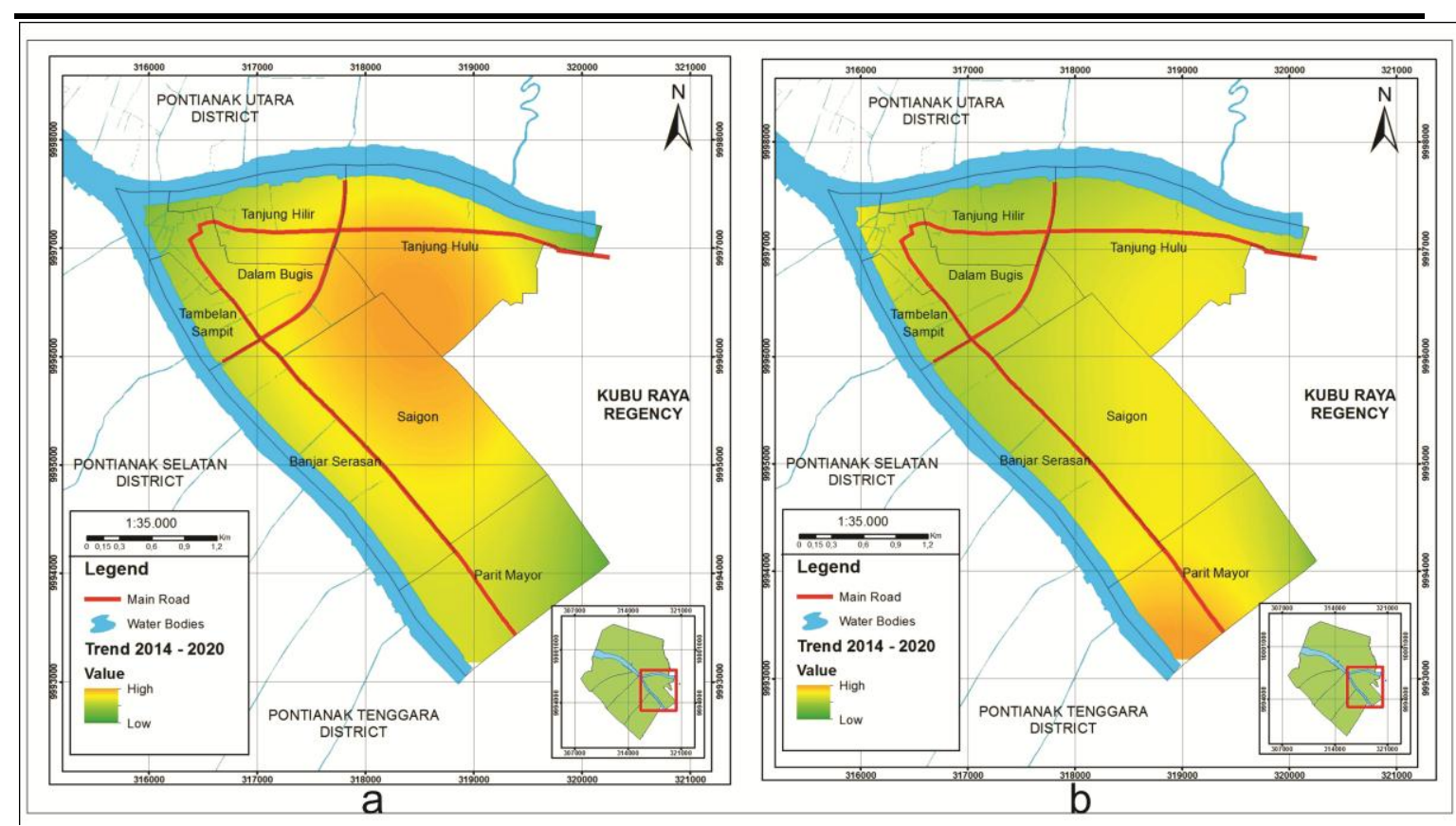

Gambar 5. (a) Peta Trend Lahan Permukiman (2003-2014); (b) Peta Trend Lahan Permukiman (2014-2020).

\section{Korelasi Banjir dan Kebakaran terhadap Prediksi Perkembangan Lahan Permukiman}

Luas permukiman menunjukkan kenaikan sebesar 419,75 Ha dan kepadatan permukiman sebesar $38,2 \%$, sedangkan luas permukiman terpapar banjir menunjukkan kenaikan sebesar 26,50 Ha atau 3,65\% (tabel 1 \& 2). Kepadatan permukiman dibandingkan dengan luas wilayah permukiman cukup proporsional dan paparan banjir juga 
menunjukkan angka yang cukup kecil, sehingga korelasi banjir dan kepadatan permukiman (dalam hal ini variabel yang mempengaruhi kerentanan kebakaran) tidak berpengaruh terhadap prediksi perkembangan lahan permukiman.

Selanjutnya berdasarkan hasil regresi logistik biner (persamaan 2) menunjukkan koefisien korelasi banjir terhadap prediksi perkembangan lahan permukiman paling kecil yaitu 0, artinya banjir tidak memiliki pengaruh sama sekali terhadap perubahan lahan nonpermukiman menjadi permukiman. Kemudian sama halnya dengan hasil analisis paparan banjir, pada variabel banjir tidak dipengaruhi sama sekali oleh perubahan penggunaan lahan dari non-pemukiman ke daerah pemukiman, itu mirip dengan persentase paparan banjir dalam jumlah yang sangat kecil (gambar 6). Dari paparan analisis diatas terdapat temuan bahwa prediksi perkembangan permukiman di tepian Sungai Kapuas Pontianak akan terus berkembang tanpa ada hambatan pada kerentanan bencana banjir dan kebakaran.

Tabel 1. Luas dan Kepadatan Permukiman

\begin{tabular}{cccc}
\hline Tahun & Luas Permukiman (Ha) & Luas Wilayah (Ha) & Kepadatan (\%) \\
\hline 2003 & 358,86 & 1098,84 & 32,66 \\
2008 & 397,35 & 1098,84 & 36,16 \\
2014 & 440,82 & 1098,84 & 40,12 \\
2020 & 481,98 & 1098,84 & 43,86 \\
\hline
\end{tabular}

Tabel 2. Luas dan Persentase Permukiman Terpapar Banjir

\begin{tabular}{cccc}
\hline Tahun & Luas Permukiman Terpapar Banjir (Ha) & Luas Wilayah (Ha) & $\begin{array}{c}\text { Paparan Banjir } \\
(\%)\end{array}$ \\
\hline 2003 & 31,65 & 1098,84 & 2,88 \\
2008 & 34,79 & 1098,84 & 3,17 \\
2014 & 39,54 & 1098,84 & 3,60 \\
2020 & 54,47 & 1098,84 & 4,96 \\
\hline
\end{tabular}

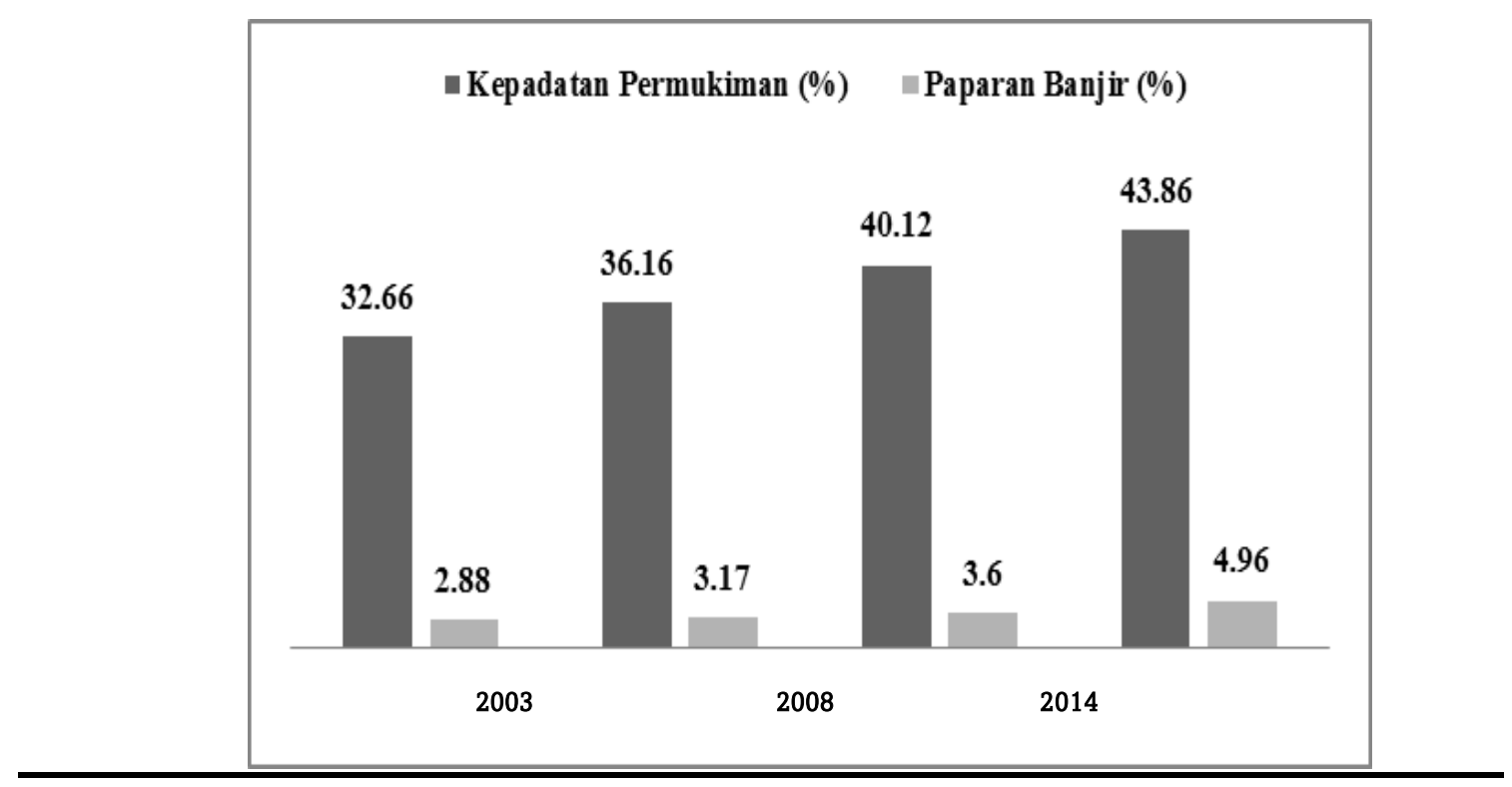

Gambar 6. Grafik Kepadatan Permukiman dan Paparan Banjir di Permukiman. 


\section{KESIMPULAN}

Hasil uji akurasi pada prediksi perkembangan permukiman di Kecamatan Pontianak Timur overall akurasi sebesar $79,74 \%$ serta indeks kappa tertinggi 0,55 . Hasil prediksi menunjukkan bahwa pada tahun 2020 lahan permukiman seluas 481,98 Ha. Selama kurun waktu 6 tahun (2014-2020) terjadi peningkatan luasan permukiman sebesar 40,81 $\mathrm{Ha}$ atau sebesar 6,80 Ha/tahun. Berdasarkan hasil analisis menggunakan interpolasi spasial polynomial orde 3 terhadap lokasi ekspansi lahan permukiman pada tahun 2020 di Kecamatan Pontianak Timur, menunjukkan wilayah perkembangan lahan permukiman cukup merata di Kelurahan Saigon, Kelurahan Tanjung Hulu, Kelurahan Banjar Serasan dan perkembangan paling tinggi di Kelurahan Parit Mayor.

Berdasarkan hasil prediksi tersebut, maka di Kelurahan Parit Mayor akan menjadi pusat perkembangan permukiman yang paling tinggi di Pontianak Timur pada tahun 2020. Hal ini disebabkan karena Kelurahan Parit Mayor masih memiliki kantong lahan nonterbangun, sehingga masih dapat dikembangkan menjadi kawasan terbangun seperti permukiman. Selain itu ditinjau dari faktor aksebilitas di Kelurahan Parit Mayor dilewati jalan utama untuk menuju jembatan penyeberangan Tol Kapuas II dan Trans Kalimantan.

Sedangkan hasil perhitungan analisis regresi biner logistik menunjukkan koefisien regresi paling besar terdapat pada variabel jarak terhadap permukiman eksisting yaitu sebesar $-0,75$. Selain itu jarak terhadap jalan utama dan tingkat kepadatan bangunan juga berpengaruh cukup tinggi terhadap perubahan lahan dari non-permukiman ke permukiman. Sama halnya pada logit perubahan lahan permukiman (2003-2008), koefisien regresi paling kecil adalah variabel banjir atau genangan yaitu 0. Oleh karena itu, variabel banjir tidak memiliki pengaruh sama sekali terhadap perubahan lahan non-permukiman menjadi permukiman di Kecamatan Pontianak Timur yang memiliki tipikal kota air.

Kemudian terdapat temuan bahwa prediksi perkembangan permukiman yang berawal dari rumah panggung di tepian Sungai Kapuas Pontianak akan terus berkembang tanpa ada hambatan pada kerentanan bencana banjir dan kebakaran. Kepadatan permukiman dan paparan banjir yang akan terus meningkat ini memerlukan arahan penataan dan pengaturan tata guna lahan, khususnya ekspansi lahan permukiman yang harus berimbang dengan ekosistem parit-sungai di Kota Pontianak sesuai tipikal aquatik.

Rekomendasi hasil integrasi CA-Markov dengan regresi logistik biner menunjukkan hasil prediksi yang cukup baik, walaupun penelitian prediksi ini dilakukan tanpa mempertimbangkan jumlah piksel maksimal yang akan berubah menjadi permukiman. Hal ini dikarenakan keterbatasan data, terutama data jumlah penduduk pada wilayah studi. Untuk penelitian selanjutnya tentang prediksi perkembangan lahan permukiman, maka perlu mempertimbangkan jumlah piksel yang akan berubah berdasarkan perkembangan jumlah penduduk, selain itu juga perlu memodifikasi metode dan data spasial yang digunakan.

\section{DAFTAR PUSTAKA}

Anunobi, A.I., (2014). Informal Riverine Settlements and Flood Risk Management : A Study of Lokoja, Nigeria, 4(12), (pp. 35-43).

Bash, E., (2009). Urban Risk Reduction: An Asian Perspective, Bingley BD16 1WA, UK.

Chander, Gyanesh and Markham, Brian. (2003). Revised Landsat-5 TM Radiometric Calibration Procedures and Postcalibration Dynamic Ranges. IEEE Transaction on Geoscience and Remote Sensing, Vol. 41, \#11, November 2003, (pp. 2674-2677).

Danoedoro, Projo. (2012). Pengantar Penginderaan Jauh Digital. Yogyakarta: Penerbit Andi.

Hasanuddin. (2015). Pontianak Masa Kolonial. Yogyakarta: Ombak.

Hegde N.P., (2008). Settlement Growth Prediction Using Neural. Journal of theoritical and applied information technology. 
IPCC. (2007). Mitigation of climate change: Contribution of working group III to the fourth assessment report of the Intergovernmental Panel on Climate Change.

Jabareen, Y., (2013). Planning the resilient city: Concepts and strategies for coping with climate change and environmental risk. Cities, 31, pp.220-229. Available at: http://dx.doi.org/10.1016/j.cities.2012.05.004.

Jaroslaw, J. \& Hildebrandt-Radke, I., (2009). Using multivariate statistics and fuzzy logic system to analyse settlement preferences in lowland areas of the temperate zone: an example from the Polish Lowlands. Journal of Archaeological Science, 36(10), (pp. 2096-2107).

Laukkonen, J. et al., (2009). Combining climate change adaptation and mitigation measures at the local level. Habitat International, 33(3), pp.287-292. Available at: http://dx.doi.org/10.1016/j.habitatint.2008.10.003.

Maria de Almeida, C. \& Marinaldo Gleriani, J., (2005). Cellular automata and neural networks as a modelling framework for the simulation of urban land use change c. Anais XII Simposio Brasileiro de Sensoriamento Remoto, Goiania, Brasil, (pp. 3697-3705).

Mentayani, I., Hadinata, I.Y. \& Prayitno, B., (2013). Karakteristik dan Formasi Keruanga Kota-Kota Berbasis Perairan di Indonesia. Lanting Journal of Architecture, 2(Nomor 2), pp.71-82.

Nema, P., Nema, S. \& Roy, P., (2012). An overview of global climate changing in current scenario and mitigation action. Renewable and Sustainable Energy Reviews, 16(4), pp.2329-2336. Available at: http://dx.doi.org/10.1016/j.rser.2012.01.044.

Nwilo, P.C., Olayinka, D.N. \& Adzandeh, A.E., (2012). Flood Modelling and Vulnerability Assessment of Settlements in the Adamawa State Floodplain Using GIS and Cellular Framework Approach. Global Journal of Human Social Science, 12(3), (pp. 11-20).

Rustiadi, Ernan et al. (2009). Perencanaan dan Pengembangan Wilayah. Jakarta: Yayasan Obor Indonesia.

Sales, R.F.M., (2009). Vulnerability and adaptation of coastal communities to climate variability and sea-level rise: Their implications for integrated coastal management in Cavite City, Philippines. Ocean \& Coastal

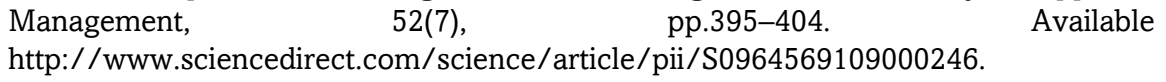

Syahar, Fitriana. (2012). Pengaruh Faktor Artifisial terhadap Perkembangan Kota. Jurnal Skala Vol.2, No.4, April 2012, (pp. 49-63).

USGS. (2015). Landsat 8 (L8) Data Users Handbook.

Watson, D. \& Adams, M.,. (2011). Design For Flooding, Architecture, Landscape, and Urban Design for Resilience to Flooding and Climate Change, Canada: John Wiley \& Sons Inc.

Wijaya, Muhammad Sufwandika., Susilo, Bowo. (2013). Integrasi Model Spasial Cellular Automata Dan Regresi Logistik Biner Untuk Pemodelan Dinamika Perkembangan Lahan Terbangun (Studi Kasus Kota Salatiga). Jurnal Bumi Indonesia Volume 2, Nomor 1, Tahun 2013.

$\mathrm{Wu}, \mathrm{F}$. (1998). "An experiment on the generic polycentricity of urban growth in a cellular automatic city". Environment and Planning B-Planning \& Design 25(5), (pp. 731-752).

Yunus, Hadi Sabari. (2010). Metodologi Penelitian Wilayah Kontemporer. Yogyakarta: Pustaka Pelajar. 